\title{
PESANTREN-BASED MADRASAH MANAGEMENT
}

\author{
Fatah Syukur \\ IAIN Walisongo Semarang
}

\begin{abstract}
Historically, the existence of madrasah can be separated from the development of pesantren in Indonesia. The rise of pesantren, as an effort to modernize the classical educational system as well as the response to the ethical politics of the colonial government, gradually got attention from community members. Nevertheless, this does not mean that madrasah developed without any problems. As an education institution, the madrasah wanted to reach progress like that of public schools. Legally, there are a number of regulations enacted to make the madrasah equal to public schools. So far the madrasah is still seen as a 'second class' school. Applying a case study on the Madrasah Roudlatul Ulum, Guyangan Pati, Central Java, this article aims to conceptualize and describe a relatively progressive madrasah and even it has a pesantren under its management.
\end{abstract}

Keywords: madrasah, pesantren, management

\section{INTRODUCTION}

The madrasah is part of the national education system in Indonesia that has the status, rights and obligations equal to public schools in general. Viewed from the history of the development of the madrasah, initially it started from the mission of preaching which becomes an obligation for every Muslim (ballighu anni walau ayah). Thus the madrasah was established in order to meet the community's demand to instill and practice religious teachings (teaching the reading of the Qur'an, carrying out the pillars of the faith, and the pillars of Islam).

The madrasah has specific characteristics, not only carrying out the duties of teaching and education of Islam, but also providing guidance to life in society. The the madrasah that serves such theological functions will run along with theological consciousness of the community based on needs to deepen and practice religious studies. Therefore, the madrasah belongs to the community and blend in with the values that have lived and grown in culture. The ideals of establishing a madrasah with regard to ibadah and getting God's blessings associated with social functions of worship should become the task of the community. This is why the madrasah is instrumental in educating the nation.

In line with efforts to reform the education system into a system that is more 
relevant to the needs of the present and the future (global community), the madrasah should be ready and able to adopt development models and new patterns in terms of organizing educational programs to improve poor education systems to bridge the demands and new challenges through three approaches: professionalism, efficiency and effectiveness, without having to leave the culture that the madrasah was born from, i.e. the pesantren.

The change from pesantren to madrasah appeared at the beginning of the 20th century as a result of feeling less satisfied with respect to the pesantren system which was too narrow and limited to the teaching of fard 'ain religious knowledge. There are at least two factors which influenced the development of the madrasah system in Indonesia: first, the factor of the Islamic reform movement; and second, the political response to the Dutch East Indies education; and the Islamic reform movement that took place in the Middle East led by Jamaluddin al-Afghani (1839-1879), Muhammad Abduh (18491905), Rashid Ridlo (1865-1935). Long before the three figures appeared, there was already a reformer namely Muhammad bin Abd Wahab (1703-1787) and Ibn Taymiyyah (1263-1328). The movements in principle were aimed at awakening the existence of Muslims who were underdeveloped as a result of the withdrawal from the intellectual and cultural practices of worship that deviated from Islamic teachings among Muslims. To bring awareness to these conditions, one of which can be done through education and the mass media to disseminate the ideas of reform.

Several figures from Indonesia, who at the time were studying in the Middle East, among others, K.H. Ahmad Dahlan and KH. Hasyim Asy'ari, brought the reform ideas to their home country. Therefore the emergence and development of the madrasah could not be separated from the Islamic reform movement initiated by a number of prominent Muslim intellectuals and then developed by Islamic organizations in Java, Sumatra and Kalimantan. In addition to the influence of Islamic reform movement in the Middle East, the emergence of the Dutch East Indies Ethical Politics movement also influenced the development of the madrasah in Indonesia. The politics of the Dutch East Indies government regarding education by opening up wider educational opportunities for indigenous people, which was originally limited to the nobility, as well as the ethical politics was an attempt of the Dutch East Indies Government to subdue the indigenous communities through education.

According to Hurgroje, that the Western education system is the best means to mitigate and ultimately defeat Islam in the Dutch colonies, because Islam would lose against Western education attraction and the unification of culture. Snouck defended this argument by pointing out the tendency that 
until 1890 the number of the pesantren was growing, while 20 years later it was the Dutch-style schools that attracted more students. With this phenomenon, at the beginning of the 20th century, the life of the pesantren went through an important change, namely the inclusion of the madrasah system/classical system into the pesantren. In a more siple language, it can be said that the madrasah to a certain degree were the Dutch educational institutions with religious subjects. It was considered the counterpart of the rapid growth of the schools who apply the Western system of education.

Education is seen as a strategic aspect in shaping the point of view of the Islamic society. In fact, education oriented too much towards religious studies (ubudiyah), as commonly found in the education conducted in mosques, surau and the pesantren, has resulted in the Islamic community evidently giving less attention to social problems, politics, economy and culture. Therefore, in order to change the views and actions of the community, the strategic step that must be taken is reforming the education system.

The success of the madrasah in preparing students to face more complex future challenges will produce graduates who will become leaders involved in determining the development of the nation. On the other hand, the failure of the madrasah in preparing students to face the challenges of the future will produce graduates who are frustrated, marginalized, and become a burden on society. Here lies the importance of efforts to improve the quality of effective management of the madrasah.

The effectively and well managed madrasah is one that has the understanding and the general philosophy, mission, goals and objectives, curriculum, effective teaching-learning strategies, and interactions with stakeholders (students, teachers, parents, environmentalists and related officials), and produce reliable graduates. An effective madrasah shows higher achievement in comparison with similar schools.

The synergy of the management of the madrasah as an educational institution with a modern system and the pesantren culture that teaches students to be independent should be in the madrasah management. The madrasah, originally born from the pesantren and still holding to the pesantren tradition are expected to not leave its cultural roots. In other words, the madrasah is expected to be able to catch up with the development of a modern system of education without leaving its roots i.e. the pesantren. Here lies the importance to formulate the pesantren-based madrasah management.

The Law of National Education System number 20/2003 puts the madrasah not only parallel to but also equal to public school. In the Law, article 17, 
paragraph 2 reads: Basic Education is in the form of Elementary School and Madrasah Ibtidaiyah (MI) or other equal forms, and junior high school (SMP) and Madrasah Tsanawiyah (MTs) or other equal forms. Next in the second part, Secondary Education article 18, paragraph 3 reads: Secondary Education is in the form of Senior High School (SMA), Madrasah Aliyah (MA), Vocational High School (SMK) and Vocational Madrasah Aliyah (MAK) or other equal forms.

From the juridical aspects, the madrasah has the same legal status, rights and obligations as public schools. Therefore, the madrasah has a strategic role for education of Muslims younger generation because it is where the majority of students prepare for their important roles for the community in the future (Arief Furchan, 2004).

In Government Regulation No. 7/2005 on National Education Standards Chapter VIII Article 49-58, the standards for education management are established by the education unit. As for the management of the educational unit in question includes program planning, preparation of curriculum, learning activities, empowerment of teachers and educators, management of educational infrastructure and facilities, assessment of learning outcomes, and supervision. In the management of the educational unit at the level of primary and secondary education, school-based management should be implemented, indicated by self-reliance, partnerships, participation, openness and accountability.

Ministry of religious affairs as a patronage of the madrasah in its 'Profile of the Future Madrasah, has stipulated that the ideal Madrasah at the level of primary and secondary education is expected to implement school-based management, indicated by self-reliance, partnership, participation, openness and accountability. The madrasah is led by the head of unit as management of education. By having several representatives at level of MTs and MA/MAK, decision making shall be done in the meeting of the Board of Educators, the Committee of The madrasah, through deliberation for improving the quality of education.

Guidelines for the madrasah shall be decided by the meeting of the Board of Educators and the Committee and shall be done in cooperation with the head of the madrasah. The guidelines specified by the head of the madrasah shall be decided after considering suggestions from the Board of Educators and the Committee. Every madrasah is managed on the basis of an annual work plan for the mid-term covering a period of 4 (four) years. The madrasah has an important mission: to prepare the younger generation of Muslims to take a role in the development of people and nation in the future. The importance of the 
Mission of these institutions due to the fact that nearly a hundred percent of the students who study at the madrasah educational institutions are the children of the family of the students. Nevertheless, the quality of the institutions that undertake this important mission, according to Arief Furchan, Ph.d., former Director of the Higher Education of Islamic Studies, is still poor. The quality of education in the madrasah outside the pesantren, especially those under Foundations with less financial support is often below standard, both in terms of religious education as well as in terms of public education.

In the field of religious education, these madrasah are relatively lower in quality compared to those under management of a pesantren, and similarly in the field of public education, they are also inferior to public schools. The madrasah in the pesantren are still somewhat passable. Although the quality of education is generally lower if compared to the standard public schools. In the field of religious education, most of them have better quality. There are indeed exceptions. There are madrasah whose quality is higher than public schools, such as MIN Malang 1, however there are only a few.

The inefficient management of the madrasah has resulted in the madrasah being left out of the public schools. On the other hand, the management of the madrasah leaving behind the pesantren system has set the madrasah away from the characteristics of the Islamic school. The effect of such management, among others, in the field of public education, the madrasah will not be able to compete with public schools, whereas in religious education it will lose to the pesantren.

The poor quality graduates of the madrasah in general will have impact on their competitiveness to enter the level of general education at the level above it. To enter a senior high school, the graduates from the madrasah generally cannot compete with public junior high school graduates. Similarly to enter public universities, they are generally inferior to public high school alumni.

The following data shows the passing grades of final exams at the madrasah in Central Java in 2004/2005:

\begin{tabular}{|c|c|c|c|}
\hline \multirow{2}{*}{ Level } & \multirow{2}{*}{$\begin{array}{l}\text { Number of } \\
\text { students }\end{array}$} & \multicolumn{2}{|c|}{ Participant } \\
\hline & & Pass & Fail \\
\hline Madrasah Ibtidaiyah & 65,175 & $62,880(96.48 \%)$ & $2,295(3.52 \%)$ \\
\hline Madrasah Tsanawiyah & 101,499 & 99,950 (98.48 \%) & $1,545(1.52 \%)$ \\
\hline Madrasah Aliyah & 29,001 & $28,559(98.48 \%)$ & $442(1.52 \%)$ \\
\hline
\end{tabular}

Source: information on Development of Education and Culture in Central Java, Office of Education and Culture, 2005

The data above shows that the number of students who failed in the final 
exam at the madrasah is still quite high. Why did that happen? How is the management of education in the madrasah done? Are the educational planning, implementation, and supervision at the madrasah not in compliance with the national standard of education?

The madrasah, as formal institutions are protected by the law and have the same rights and obligations as other formal educational institutions, should be able to compete in producing quality graduates.

The question is "why are most of the madrasah far from ideal? Why do madrasah graduates in general fail to compete with public school alumni? How should madrasah be managed so as to ideally meet the standards as stipulated in legislation and government regulations?

In this light, the author intends to conduct research on the private madrasah that have pesantren as its base, namely the Madrasah Raudlatul Ulum Guyangan Pati. At this Madrasah, the pesantren and the madrasah are under the same management. The headmaster is also a teaching staff of the pesantren. All the pesantren students are also the students of the madrasah and all the subjects are included in the madrasah curriculum.

The excellence in management is expected to be emulated by other madrasah and conceptualized into the pesantren-based madrasah management which includes program planning, preparation of curriculum, learning activities, empowerment of teachers and educators, as well as infrastructure and facility management.

This paper aims to gain more concrete picture of the pesantren-based madrasah management in three madrasahs. This study is expected to formulate a concept of an ideal pesantren-based madrasah management. To achieve that, a will be used. The following table indicates the data sources and data collection techniques:

\begin{tabular}{|l|l|l|}
\hline \multicolumn{1}{|c|}{ Data } & \multicolumn{1}{|c|}{ Source } & \multicolumn{1}{c|}{ Collection technique } \\
\hline $\begin{array}{l}\text { Education Program } \\
\text { Planing }\end{array}$ & $\begin{array}{l}\text { Head of madrasah, head of } \\
\text { Pesantren, Committee of } \\
\text { Madrasah }\end{array}$ & $\begin{array}{l}\text { Documentation and } \\
\text { interview }\end{array}$ \\
\hline $\begin{array}{l}\text { Curriculum prepa- } \\
\text { ration }\end{array}$ & $\begin{array}{l}\text { Head of } \text { madrasah, head of } \\
\text { Pesantren, and Vice headmas- } \\
\text { ter for curriculum }\end{array}$ & $\begin{array}{l}\text { Documentation and } \\
\text { interview }\end{array}$ \\
\hline Learning activities & $\begin{array}{l}\text { Head of } \text { madrasah, head of } \\
\text { Pesantren, and teachers }\end{array}$ & $\begin{array}{l}\text { Observation, Documenta- } \\
\text { tion and interview }\end{array}$ \\
\hline $\begin{array}{l}\text { Management of facil- } \\
\text { ities and infrastruc- } \\
\text { ture of Madrasah }\end{array}$ & $\begin{array}{l}\text { Head of } \text { madrasah, head of } \\
\text { Pesantren, and Vice headmas- } \\
\text { ter for facilities and infra- } \\
\text { structure }\end{array}$ & $\begin{array}{l}\text { Observation, Documenta- } \\
\text { tion and interview }\end{array}$ \\
\hline
\end{tabular}


Meanwhile, the data analysis used in this study is the analysis of qualitative data, following a concept proposed by Miles, Huberman and Spradley. Miles and Huberman (1984), suggested that activities in the qualitative analysis should be done interactively and run continuously at each stage until the research is completed, and the data has reached a saturation point. Activities in the data analysis include data reduction, data display, and conclusion drawing/verification. The three strands of activities can occur simultaneously, namely: data reduction (classifying, directing, organizing and disposing of unnecessary data), data display (finding patterns of significant relationships and providing opportunities for conclusion drawing) and conclusion drawing/ verification (making a pattern of meaning about events that occurred).

Furthermore, according to Spradley, the technique of data analysis can be tailored to the stages in the research. At this stage of exploration with the data collection technique of grand tour question, data analysis is done with the analysis domain. At the stage of determining the focus, the data analysis is conducted using the taxonomy analysis. At the stage of selection, data analysis can be done with the componential analysis. The next stage will generate the title with the analysis of the theme.

\section{MADRASAH RAUDLATUL ULUM}

\section{Portrait of the Madrasah}

The atmosphere of a student village is obvious when entering the path to the village of Guyangan. The santri (students of pesantren) as well as students, can be seen walking to attend school (madrasah). Male students attend school in the morning while female attend in the afternoon. As for madrasah diniyah, male students attend during in the afternoon and female attend in the morning. As reported by KH. Humam Suyuti in the ceremony welcoming the new students of Madrasah Raudlatul Ulum, July 13, 2008:

"The students in this madrasah do not for six days, but nine days, six days at the formal madrasah and three days at madrasah diniyah". There is almost no time left for students here for lazing. The new students, especially students of MTs, in addition to adjusting to the boarding school environment, they are required to memorize Alfiah verses as many as 1000 verses within three years. "Everywhere we go we take with us the 'pocket book' so that we can read and study, particularly the lessons to be memorized, such as Alfiah ibn Malik manuscript," said 'Abiq, a new MTs student from Semarang.

Madrasah Raudlatul Ulum is part of the Raudlatul Ulum boarding schools. When one looks around, they can see the more dominant symbols of the 
Islamic boarding schools compared to the name of the madrasah. For example, the logo used as a symbol of the Islamic boarding school bears the 'Pesantren Raudlatul Ulum' instead of 'Madrasah Raudlatul Ulum'. Likewise, a banner, installed at the time of the visit by the Director of the Madrasah of the Ministry of Religious Affairs, Drs. H. Firdaus, M. Pd. on July 26, 2008, also read "Welcome to Pesantren Raudlatul Ulum" instead of "Welcome to Madrasah Raudlatul Ulum".

The creation of a boarding school climate at this madrasah is quite noticeable. The students of the madrasah are also students of the pesantren and the lessons are integrated in one curriculum. Therefore, the evaluation undertaken here not only includes curriculum material from Ministry of Religious Affairs and Ministry of Education, but also manuscripts. Students will not be able to be promoted to a higher level if their academic achievement is poor, or if they fail to memorize the required manuscripts, or if they do not behave. These three components are inseparable. Anyone who has not met these three targets has to stay in the same class for another year. Gus Najib (Drs. KH. Najib, M. Ag.) reported that his nephew did not meet the target of these three components, and he had to retake the class.

Geographically Madrasah Raudlatul Ulum is located in the village of Guyangan, Sub-district of Trangkil, District of Pati, Central Java. The village is located approximately $80 \mathrm{~km}$ from Semarang the capital of Central Java, and about $15 \mathrm{~km}$ from the city of Pati. Its position is very strategic, located in the middle of the community and the mosque, not far from public transportation (between Juwana and Tayu).

At the beginning of the establishment of Madrasah Raudlatul Ulum, it was named Madrasah Manba'ul Ulum (MMU), which was established by alMaghfurlah KH. Suyuti Abdul Qodir in 1929 in the village of Guyangan. As the situation did not allow for developing educational institutions due to pressure from the colonial Government in 1940, Madrasah Manba'ul Ulum experienced a total stagnation.

Then, after independence in 1950, with support and help the scholars and public figures, Madrasah Manba'ul Ulum was revived by KH. Suyuti Abdul Qodir with a new name i.e. Raudlatul Ulum.

At the beginning of its establishment until 1955, Madrasah Raudlatul Ulum used the following terms to indicate the level of education: Shifir Awal, Shifir Tsani, dan Shifir Tsalis. Seven years later, in 1962, the terms were changed to PGAP 4 years and Takhoshush 2 years. Over the next decade changes were made again to PGAP 4 years and PGAL 2 years. 
In order to reorganize the management and to meet the demands of the development of education, in 1972, in front of a Notary Public in Kudus, RM. Mardagoeng Poerbokoesoemo, an institution bearing the name the Foundation of Islamic School of Raudlatul Ulum (YPRU) was formally established, under the establishment Certificate number: 17/1972 dated January 26, 1972. Later in 1974, the education system PGAP PGAL 4 years and 2 years was changed to Mts 3 years and Madrasah Aliyah 3 years.

Then in 1993 the accreditation level of Madrasah Aliyah Raudlatul Ulum was upgraded from 'Listed' to be 'Recognized' by the Ministry of Religious Affairs. In 1997 Madrasah Aliyah Raudlatul Ulum was fully accredited (Muadalah) from al-Azhar University of Cairo. And in 2000 Madrasah Aliyah Raudlatul was fully accredited by the Ministry of Religious Affairs. Today, Madrasah Aliyah and Madrasah Tsanawiyah Raudlatul Ulum have been accredited 'A' by the Accreditation Council of Madrasah (DAM) of the Ministry of Religious Affairs.

The Foundation of Islamic School of Raudlatul Ulum (YPRU) currently runs the following educational institutions: Madrasah Ibtidaiyah (accredited B), Madrasah Tsanawiyah, and Madrasah Aliyah (accredited A). In addition to formal institutions, YPRU also runs Madrasah Diniyah to prepare students to enter Madrasah Tsanawiyah.

Basically all registrants at YPRU will be admitted as pupils/students. They usually have to take an entrance test. However, the test here is not to determine admittance, rather it is used for placement; whether they can be admitted directly in the Madrasah Tsanawiyah or Madrasah Aliyah, or madrasah diniyah first. According to KH. Humam Suyuthi, the reason why all applicants are admitted is because this madrasah belongs to the community.

"If we make a selection and the results turn out to be those from outside Guyangan being admitted, we will receive protests. Therefore, all applicants will be admitted. They will be placed based on their test scores. Let the natural selection determine if they can survive here. The learning system here is very tight. To be promoted to a higher level, one must pass three qualifications: good academic results, good manners good and good memorization. "

Since its foundation, this boarding school continued to show rapid growth. In the past, the school had only a dozen students, but there were up to 3,000 students in 2007/2008 academic year. The infrastructure was previously very simple, but currently it is quite sufficient.

Upon the death of the founder, this pesantren was taken care of by his sons. At first, it was $\mathrm{KH}$ Salim Suyuthi who was in charge. However, after $\mathrm{KH}$ 
Salim passed away, the chairmanship was held by the other three sons of the founder: KH Faruq Suyuthi, Drs. KH Humam Suyuthi, MHI, and Drs. KH Najib Suyuthi, M.Ag. The internal affairs were handled by KH Faruq and KH Najib. While the public relations were handled by Drs. KH Humam Suyuthi, M.H.I. He has forged good relations with the Middle East and other countries to develop the boarding school. His good relations have made the pesantren famous both at home and abroad. One of the Madrasah Aliyah buildings was funded by his colleague from Malaysia, Prof Dr HM. Saleh Suwandi.

KH Humam has two sons: Muhammad Zuhrufus Zaman, currrently doing Ph.D in Malaysia, and Nur Iffah --the second son-- is studying medicine at Sultan Agung Islamic University in Semarang (UNISSULA).

\section{Educational Planning of pesantren-based madrasah}

Educational Planning programs should be "future oriented". This means that the intended goals in the planning of education can be expected both in the short and long terms. The definition of short and long terms here is very relative. Generally short term educational planning is for around 1 year, midterm 5-10 years and long term 25-30 years.

Educational planning is oriented on a strategy of action. Thus education planning not only collects data and information or spreads information but it also includes goal oriented activities. It means that any action needs to be arranged in an efficient pattern so that the intended purpose can be achieved with the most economical ways and tools.

The education planning programs of Madrasah Raudlatul Ulum Guyangan can be seen from its vision, mission and objectives. It's vision is "A step further in the achievements with science and charity."

Indicators of the vision are:

a. more advanced in mastering the science of al-diniyah (the salaf manuscripts)

b. more advanced in an effort to ensure graduates to be admitted at Higher Educational Institutions (both religious and public) both within the country and abroad.

c. more advanced in creativity.

d. more advanced in arts.

e. more advanced in sport.

f. more advanced in discipline.

g. more advanced in religious practices. 
h. more advanced in social concern.

i. more advanced in mastering Arabic and English.

While the missions are:

a. Developing and preserving the teachings of Islam.

b. Improving the quality and development of Islamic sciences (tafaqquh fiddin) that are relevant to the demands of the times in the context of the present and the future in order to form quality human resources that are knowledgeable, put their knowledge in to practice and have good manners.

c. Establishing the institution as a center of learning for Islamic knowledge development network that competitive and relevant to the demands of science and technology.

As for the objectives of Madrasah Raudlatul Ulum are as follows:

\section{Short term goals:}

a. Encouraging the improvement of efforts to ensure that the graduates will be admitted to higher educational institutions (religious and public) at home and abroad.

b. Having potential students in the selection of exemplary students both at the district and provincial level.

c. Having a sports and arts team that is capable of competing in various events both at the district and provincial level.

\section{Long-term goals:}

a. Making efforts to ensure as many graduates as possible to be admitted to colleges and universities (religious and public) both at home and abroad.

$b$. Having a group of teenagers who write scientific papers to compete at district and provincial level.

c. Having a scout team that is capable of working and competing in the Regional or National Jamboree.

The description of the vision, mission and goals of the Madrasah Raudlatul Ulum reflects that boarding school system and culture has always been a base for the development of educational programs at the madrasah.

\section{Curriculum and Learning Activities}

Raudlatul Ulum pesantren is an "integrated" type of boarding school that carries out the education system of the salaf and khalaf. The education system of the salaf teaches Islamic studies from the yellow books written by scholars 
of the salaf. The curriculum in the education system of the salaf is based on the level from easy to difficult depending on of the issues discussed in the book. The system used was a tiered system, i.e. from beginner, intermediate and advanced combined in formal education and evaluated in accordance with the level of formal education. The manuscripts used for teaching, among others: Sanusiyah, Aqidatul Awam, Tafsir Jalalain, Durrotun Nasihin, Fatkhul Qarib, Taqrib, al-Iqna', Irsyadul Ibad, al-Maqsud, Alfyah Ibnu Malik, dan Ta'lim Muta'allim. the Khalaf system used by the Raudlatul Ulum boarding school is a madrasah system from formal elementary to senior high school level, fully implementing the curriculums of the Ministry of religious affairs and the Ministry of national education. The field of religious studies that refer to the curriculum of the Religious Ministry taught with additional locally-designed materials (al-ulum ad-diniyah).

Basically all students that study at Raudlatul Ulum are YPRU students because of the lessons taught at the madrasah and the pesantren are integrated. The students at Raudlatul Ulum Boarding School can be grouped into two categories, namely, the students who live at the boarding school and those who do not. Students from outside the city or is more than $10 \mathrm{~km}$ away from the school are required to live at the boarding school, while those who live nearby are not required to. Both groups of students above have to study yellow books and join extra-curricular activities in the morning or in the afternoon. Especially for the students who live at the pesantren, there are extra lessons, i.e. every evening after sunset they hold book studies known as MMK (manuscript reading). The manuscripts discussed among others: Riyadus Sholihin, Tuhfatul Atfal, Tuhfatul Ain and so on. MMK is directly taught by KH Human, KH. Faruq dan KH. Najib. In addition to the study of the book, there are also auditions, drama rehearsal, khitabah, etc. On Thursday evening, there is recital of majmuk al-Barjanzi.

The following books are also studied: nahwu, sharaf, bahasa arab, fiqih, tafsir, hadits, tauhid, akhlaq, tajwid, etc. which are included in school curriculum and evaluated like other subjects.

Regarding book studies at the pesantren integrated into the madrasah curriculum can be seen from the list of books used, among others: 
a. Madrasah Ibtidaiyah

\begin{tabular}{|c|l|c|l|}
\hline No. & \multicolumn{1}{|c|}{ Name of book } & No. & \multicolumn{1}{|c|}{ Name of book } \\
\hline 1. & Nahwu Wadih & 7. & Kharidah Bahiyah \\
2. & Amsilatu-tasrifiyah & 8. & Fatkhul Majid \\
3. & Lughah Arabiyah & 9. & Akhlaq al-Banin \\
4. & Durusu Fiqhiyah & 10. & Khulasah Nurul Yaqin \\
5. & Tafsir Jalalain & 11. & Tuhfah al-Atfal \\
6. & Arbain Nawawi & & \\
\hline
\end{tabular}

\section{b. Madrasah Tsanawiyah}

\begin{tabular}{|c|l|c|l|}
\hline No. & \multicolumn{1}{|c|}{ Name of book } & No. & \multicolumn{1}{|c|}{ Name of book } \\
\hline 1. & Latahoif Isyarah & 7. & Matan Rahabiyah \\
2. & Jauhar Maknun & 8. & Alfyah ibnu Malik \\
3. & $\begin{array}{l}\text { Dasuqi al-Husun al-Hamidi- } \\
\text { yah }\end{array}$ & 9. & Durusul Falakiyah \\
5. & Taklim Muta'allim & 10. & Minhajul Mughis \\
6. & Tafsir Jalalain & 11. & Mukhtasar as-Syafi'i \\
\hline
\end{tabular}

\section{c. Madrasah Aliyah}

\begin{tabular}{|c|l|c|l|}
\hline No. & \multicolumn{1}{|c|}{ Name of book } & No. & \multicolumn{1}{|c|}{ Name of book } \\
\hline 1. & Fatkhul Wahab & 7. & Tajrid al-Sarih \\
2. & Ghayah al-Wusul & 8. & Idah al-Bubham \\
3. & Jauhar Maknun & 9. & Fath al-Rauf al-Manan \\
4. & Faraidh Bahiyyah & 10. & Ulum al-Tafsir \\
5. & Tafsir Jalalain & 11. & Tarikh Tasyrik Islami \\
6. & Maroki al-Ubudiyah & & \\
\hline
\end{tabular}

The earning method used for book studies is called bandongan system and sorogan system. In the bandongan system, the teacher reads a book, and the students do the maknani, listen and write the meanings not yet fully understood. In Maknani system, the students not only translate the meaning to another language (Javanese), but also explain the meaning, position of a 
word in a sentence and give other explanations. In the maknani process the students also study nahwu, sharaf, balaghah and so on.

Meanwhile, the sorogan system is usually aimed at memorizing certain books and then reciting the verses of the book before their teacher.

The focus of learning YPRU pesantren is studying Islamic law while also studying the general sciences. Both are taught together. For instruction at the madrasah, the assessment system is exactly the same as that held at public schools, i.e. formative and summative tests. The book studies at the pesantren are assessed on the basis of students' memorization.

\section{Extra-curricular activities}

Extra-curricular activities at this boarding school include sports activities, art, skills as follows:

a. Book reading

b. Bahsul masail ad-diniyah

c. Speech exercise

d. Qur'an reading

e. Arabic course

f. English course

g. sewing and embroidery course

h. Scouting

i. martial arts

j. basketball

k. Marching band

b. decorating skills

d. Yellow Book studies

n. music

o. journalistic Practice.

p. Red Cross

q. Basic Training Course (BATRA)

$r$. Household maintenance course

s. Student cooperative

t. wall Magazines, etc.

In addition to these activities, the boarding school also organizes incidental activities, for example muwadda'ah/akhirussanah. Commemorative activities 
of Islamic major holidays, and so on.

\section{Facilities and Infrastructure}

In brief, the facilities owned by YPRU consist of: mosques, Qur'an reading room, classrooms for kindergarten/RA, MI, MA, MTs, Secretariat/Administration/ Office, library, natural science laboratory, language laboratory, the telephone booths, kitchen, student rooms, school cooperative, guest rooms, bathrooms, convenient rooms, living room, teacher housing and warehouses.

The facilities based on level of education, consist of:

a. Kindergarten/RA (Raudlatul Athfal)

b. MI Raudlatul Ulum, Accredited B.

c. Madrasah Diniyah Raudlatul Ulum:

- MDPTs (Preparatory school for Madrasah Tsanawiyah). Since three years ago it has been combined with Madrasah Tsanawiyah. Those who enter this Madrasah Diniyah can directly study in MTs.

- MDPA (Preparatory school for Madrasah Aliyah), for students who come from public high schools or other Islamic high school who did not pass the selection placement at Madrasah Aliyah Raudlatul Ulum.

d. Madrasah Tsanawiyah Raudlatul Ulum, the Accredited Status 'A' and 'fully accredited" by al-Azhar University Cairo, Egypt.

e. Madrasah Aliyah Raudlatul Ulum, the Accredited Status 'A' and 'fully accredited" by al-Azhar University Cairo, Egypt. This chool has three main program options: natural science, social science, and language programs.

f. Madrasah Ibtidaiyah, Raudlatul Ulum boarding school branches

g. LPPBA Raudlatul Ulum (Arabic language improvement center)

h. ECC RU (English Conversation Club Raudlatul Ulum) particularly for female students.

i. Raudlatul Ulum economics center

j. PIK2M Raudlatul Ulum (information and family consultation center)

k. USP Raudlatul Ulum (loans and savings unit)

l. English Speaking Progrma of Raudlatul Ulum (ESP-RU) particularly male students.

m. Raudlatul Ulum religious study club

n. KBIH (Hajj guidance) Ar-Al-Rawdah.

This pesantren covers an area of more or less 6 hectares, comprising:

a. Male students dormitory on the $2^{\text {nd }}$ floor (2 units), and on the 3 rd floor (one unit) 
b. Female students Dormitory on the 2nd floors (3 units)

c. buildings for Madrasah Ibtidaiyah, Diniyah, Tsanawiyah, and kindergartens with 24 classrooms in total.

d. Building for senior high school on the 3rd floor having18 classrooms

e. Building for senior high school on the 3rd floor having18 classrooms (Prof. Dr. H. Moh. Saleh Suwandi Malaysia building) having 8classrooms.

f. Building for MTs on the $3^{\text {rd }}$ floor with 9 classrooms

g. Computer laboratory

h. Language laboratory

i. Natural science laboratories

j. tailoring workshop building

k. cooperative building

l. Cairo Al-Azhar Lecturers housing

m. teachers office

n. Library

o. Auditorium

p. etc.

The facilities and infrastructure are under the management of the madrasah and the pesantren.

\section{Student Administration System}

Admissions into the pesantren and the madrasah take place at the same time which is at the start of a new academic year. Prospective students can enroll earlier that the admissions date in order to get used to the boarding school.

There is no special selection in the admissions of prospective students. They walk in with parents and bring with them a to whem it may concern letter from a village chief. There is a placement test.

The cost of living at the pesantren is relatively cheap. The educational activities cost IDR 3,500 monthly; and registration IDR 20.000; building fee IDR 175,000; the cost of meals IDR 180,000/month for three time meal a day. Starting Syawal 1429 H, it was increased to IDR 200,000/month. There are students who have catering service for meals; some cook by themselves.

In General, all students should not be out of the pesantren, unless there is an emergency and should get permission from the teacher. The pesantren complex is equipped with fences and locks. The gate is only opened in the hours of starting and finishing school, and ahead of the maghrib (sunset 
prayer). Except for these hours, students should not be out of the pesantren. Male students are kept separate from female students. They should be dressed in Muslim attire and keep the good name of the pesantren. If they violate the rules, then they will get sanctions/takzir.

The dorms for male and female students are separate. The students are always supervised by the teachers, senior students as well as by the managers of the boarding school. Similarly, in their formal schooling, boys and girls are also kept separate.

The meals at this pesantren are not managed by the management but instead there is a person appointed to take care of the matter. There is also a snack stall and only a handful of students who cook for themselves.

The placement of students in certain dorms is not based on the region of origin, rather it is according to the kind of education they attend. The number of students who live at the pesantren and those who come only during lessons is 2,967 consisting of 1,391 females and 1,644 males. The number of those who live at the pesantren is 2,057 and those who live at their home 1,080.

The data of YPRU Guyangan alumni in detail can be found in the profile of alumni book. In general after they complete their studies at the pesantren, these alumni continue their education at home and abroad. For overseas universities, they usually continue to al-Azhar University, Egypt. As for the domestic colleges, they go to among others Gadjah Mada University, Yogyakarta; UNDIP Semarang, IAIN, UNNES, UNISSULA and so on.

All students who live at the pesantren are required to remain within the pesantren compound unless there is an emergency and should get permission from the teacher/supervisor. The student activities are mostly around the pesantren and around the mosque and the madrasah.

\section{DISCUSSION}

The pesantren as one of Islamic educational institutions have proved its existence and its success in improving the human resources. In the last century, it has been proved that a lot of community and national leaders came from the pesantren. the pesantren have also given the nuances to the pattern of people's lives in the vicinity. In other words, the pesantren is also a solid defense in the face of cultural influence which is not in accordance with the divine values.

History has recorded the achievements of the pesantren as a unique Islamic culture forming known as "Javanese santri culture". The uniqueness of the pesantren lies in its craftiness in combining the local culture with the substance 
and spirit of Islamic life.

The pesantren as an institution is very potential. This is due to the fact that the pesantren has a historical root of solid ideology and culture. The power of the pesantren also lies in its consistency such as "jihad war in fighting against the invaders."

According to $\mathrm{KH}$ Humam Suyuthi, the main challenges the pesantren faces is not only against the invaders in physical form but it should also show its existence as an institution capable of shaping the future leaders equipped with worldly and religious sciences. The two are inseparable. He did not agree with the notion that there should be a separation between religious and nonreligious knowledge. Therefore, the santris are trained here to master general and religious sciences. For those who wish to continue to study religious studies, they go to the Middle East while those who are interested in general sciences choose to continue to public universities.

In addition, the santris also learn three international languages i.e., Arabic, English and Mandarin. Arabic teachers from al-Azhar University Egypt have created an active learning atmosphere of Arabic at the Raudhatul Ulum pesantren.

From the history we learn that the greater challenge faced by the pesantren, the more resistant and sophisticated the pesantren has become. When the Dutch tried to restrict the religious life in the second half of the 19th century, two pesantren ulama of international caliber namely Nawawi al Bantani (died in 1897) dan Mahfud Termaz (1868 - 1919) who are both known as Imamul Haramain, professors in Mecca and Medina with papers all written in Arabic. The two productive scholars is a phenomenon of the pesantren which is rarely known. The pesantren is often seen as a world of oral speech, and podium. One needs to read the history as a whole to have a balanced view.

The pesantren as the academic Muslim community should be able to bridge a dialogue with modern culture, and actively fill it with Islamic substance and nuances. This can only be done if we understand the meaning of globalization correctly and keep ourselves updated with the actual information and the global trend.

Changes are not something new. The pesantren has been familiar with the principles of al-Muhafadhah ala qadim al-shaleh wa al-ahdu bi al-jadid alashlah meaning "preserving good tradition and adopting a better innovation". In the past, the pesantren was considered to be a neglected place and a kyai was a traditionalist figure, and now the impression has to be left away.

The keyword to anticipate changes in the present and the future is information 
and knowledge. The two words mentioned is not a new for the Muslims. From the time of the Prophet until the 11th century, Islam was able to bridge a dialogue with the era, and was even capable of converting many people in many areas. This progress was certainly impossible without a basic understanding of how to appreciate time, civilization, the value of knowledge and information among the Muslims.

In this era of globalization, to face the free market the peantren needs to improve the quality as a solid 'defensive fortress'. It is difficult to achieve if the pesantren does not a strong, prospective vision, and an effective managerial system.

Prophet Muhammad said that everyone will be useless except those who think; the educated will be useless except those who practice their knowledge; people who practice their knowledge will be useless except those who do with sincerity. Therefore the purpose of Islamic education is to promote morals, improve manners, promote humanitarian values to draw closer to God. AlGhazali, with his fine teachings, is of course still a main reference for the world of the pesantren.

However, it does not mean that Islam ignores the science that teaches specific skills. All sciences that bring benefits to humans must be learned. Any form of science, technology, mathematics, astronomy, etc., should be studied and should promote better morals, so that people will be aware of the responsibility of their knowledge. This should be based on the Islamic values, so people who think and find out the secrets of nature will bring benefits to others. AlGhazali taught that knowledge that comes from outside should be sorted out to fit in accordance with the Islam laws. In addition, basically all sciences are useful unless it is in the hands of unscrupulous individuals.

\section{CONCLUSION}

Educational program planning at the Madrasah Raudlatul Ulum Guyangan can be seen in the vision, mission and goals of the madrassa that reflects that the cultural system of the pesantren has always been a base for the development of its educational programs. As explored, the Raudlatul Ulum Pesantren is a kind of school classified as an "integrated" pesantren as it carries out the education system of the salaf and khalaf aimed at balancing between the religious values and modernization. 


\section{REFERENCES}

A. Shalaby, History of Muslim Education, Beirut: Daar el Kashaf, 1954.

A. Shamad Hamid, Islam dan Pembaharuan, Surabaya: Bina Ilmu, 1984.

Abd al-Madjd Abd al-Futuh Badawi, al-Tarikh al-Siyasi wa al-Fikri, Beirut: al-Manshur Mathobi' al-Wafa, 1988.

Ali Yafie, Tajdid adalah Suatu Kemestian, Pesantren, No.I Vol.V 1988.

Azyumardi Azra, Pendidikan Tinggi Islam dan Kemajuan Sains (sebuah pengantar), dalam Charles Michael Stanton, Pendidikan Tinggi dalam Islam (terj.), Jakarta: PT. Logos Publishing House, 1994.

Bryson, John M., Perencanaan Strategis bagi Oraganisasi Sosial (terj. M. Miftahuddin), Pustaka Pelajar, Yogyakarta, 2000, C.II.

Departemen Agama RI, Nama-nama dan data Potensi Pondok-pondok Pesantren seluruh Indonesia, Jakarta: Departemen Agama dan P3M, 19841985.

Djamil Latief, Himpunan Peraturan-peraturan tentang Pendidikan Agama, Jakarta: Ditbinpendais Depag RI.

E. Mulyasa, Dr., M. Pd, Menjadi Kepala Sekolah Profesional dalam Konteks Menyukseskan MBS dan KBK, PT. Remaja Rosda Karya, Bandung: 2003.

E. Mulyasa, Pedoman Manajemen Berbasis Madrasah, Departemen Agama RI 2004, hlm 83.

Ensiklopedi Islam, Jakarta: PT. Ichtiar Baru van Hoceve, 1993.

George R. Terry dan Leslie W. Rue, Dasar-dasar Manajemen, Bumi Aksara, Jakarta:2003

Ghulam Farid Malik, Dr., Pedoman Manajemen Madrasah, Yogyakarta: Basic Education Project (BEP) Depag RI bekerjasama dengan Forum Kajian Budaya dan Agama (FKBA), 2000.

H.A.R. Tilaar, Prof., Dr., M. Sc. Ed., Manajemen Pendidikan Nasional Kajian Pendidikan Masa Depan, PT. Remaja Rosda Karya, Bandung:1999.

Haidar Nawawi, Perundang-Undangan Pendidikan, Jakarta: Ghalia Indonesia, 1983

IP. Simanjutak, Perkembangan Pendidikan di Indonesia, Jakarta: Departemen Pendidikan dan Kebudayaan, 1972/1973.

Ira Shor \& Paulo Freire, Menjadi Guru Merdeka, LKiS, Yogyakarta, 2001.

Karel A Steinbrink, Pesantren, Madrasah, Sekolah, Jakarta: LP3ES

MA. Sahal Mahfudh, Madrasah dari Masa ke Masa, dalam Nuansa Fiqih Sosial, Yogyakarta: LKiS, 1994.

Mahmud Yunus, Sejarah Pendidikan Islam di Indonesia, Jakarta: Mutiara Sumber Widya, 1995.

Majlis Ulama Indonesia., Amanat Sejarah Ummat Islam Indonesia, Keputusan 
Rapat Pengurus Paripurna ke II, Jakarta: Sekretariat MUI, Masjid Istiqlal, 1986.

Maksum, Madrasah Sejarah dan Perkembangannya, Jakarta: Logos, 1999, hlm 60.

Marwan Saridjo, Drs., Bunga Rampai Pendidikan Agama Islam, Jakarta: CV. Amisco, 1996.

Mastuhu, Dinamika Sistem Pendidikan Pesantren, Jakarta: INIS, 1994.

Mulyanto Sumardi, Sejarah Singkat Pendidikan Islam di Indonesia 1945-1975, Jakarta: LPAIAK Balitbang Agama Depag, $1977 .$.

Mas'ud, Abdurrahman, Why the Pesantren in Indonesia Remains Unique and Stronger, College of Islamic Studies PSU Pattani: Paper 25-28 June 1998.

Pitts Robert, A. and Lei, David, Strategic Management, Building

R. Edward Freeman, Manajemen Strategik, Jakarta, PT. Pustaka Binaman Pressindo, 1985.

Ratminto dan Atik Septi Winarsih, Manajemen Pelayanan, Yogyakarta: Pustaka Pelajar, 2005.

Soebagio Atmojdiwirio, Manajamen Pendidikan Indonesia, Ardadizya Jaya, Jakarta, 2000.Ibtisam Abu-Duhou, School-Based Management, Logos, Jakarta, 2002.

Sondang P. Siagian, Prof., Dr., Analisis serta Perumusan Kebijaksanaan dan Strategi Organisasi, CV. Haji Masagung, Jakarta:1994.

Undang-Undang Republik Indonesia, Nomor 14 Tahun 2006, tentang Guru dan Dosen

UU Sisdiknas No. 20 tahun 2003, Sinar Grafika, Jakarta: 2003

Wasty Soemanto, Landasan Historis Pendidikan Indonesia, Surabaya: Usaha Nasional, 1983.

WJS. Poerwadarminta, Kamus Umum Bahasa Indonesia, Jakarta: Balai Pustaka, 1990.

Zamakhsyari Dhofier, Tradisi Pesantren, Jakarta: LP3ES, 1985.

Zamakhsyari Dofier, dkk, Kebijakan Departemen Agama dari Masa ke Masa Dalam kurun Setengah Abad, Jakarta: Badan Litbang Agama Departemen Agama RI, 1996.

Zuhairini, dkk, Sejarah Pendidikan Islam di Indonesia, Jakarta: Dirjen Binbaga Islam, 1986 